\title{
The Impact of the Anti-Chinese Páihuá Policy in Vietnam after Reunification: the Refugees'
}

\section{Perspective}

\author{
Martina Vuong
}

\begin{abstract}
In 1978-1979 the news reporting on the Vietnamese boat people attracted attention from the whole world. Not only the media but also scientific researchers were interested in these mass refugees. However, this phenomenon has been detached from its context and perceived as a selfcontained event on many occasions. Furthermore, most people were not aware of the fact that the main body of these refugees were ethnic Chinese, known as the Hoa. The study presented in this paper takes this as its starting point and focuses on the question of the motivations of the Hoa in leaving North Vietnam. It takes the historical, internal and foreign political context into consideration and identifies a political atmosphere extremely hostile to the ethnic Chinese.The páihuá policy drove them to leave behind what they had built up and led to the mass exodus of 1978-1979, but also gave the Hoa hope for a new and better life for themselves and especially for their future descendants outside of Vietnam.
\end{abstract}

Keywords: boat people, Chinese, Hoa, páihuá, Sino-Vietnamese relations, Vietnam

Vuong, Martina. "The Impact of the Anti-Chinese Páihuá Policy in Vietnam after Reunification: the Refugees' Perspective." In Vienna Graduate Journal of East Asian Studies, Volume 2, eds. Rudiger Frank, Ingrid Getreuer-Kargl, Lukas Pokorny and Agnes Schick-Chen. Vienna: Praesens Verlag, 2011, pp. 149-170.

https://doi.org/10.2478/vjeas-2011-0012 


\section{Introduction}

From 1978 to 1979, thousands of ethnic Chinese (Hoa) started their journey to the People's Republic of China (PRC, China), to Hongkong or to Macao by either land or sea. 'Hoa' is the abbreviation for the Vietnamese term hoa kiều-in Chinese huáqiáo 华侨 (overseas Chinese) - and these people made up to 90 percent of the whole number of refugees (Will 1988: 177). In the West they are known under the label of 'boat people', indicating their characteristic means of fleeing from Vietnam-by boat.

In the period 1945-1975 Vietnam was constantly at war, a situation that was accompanied by various refugee movements. After the First Indochina War (19461954), Vietnam was able to gain independence from French colonial dominance in 1954. One consequence was that the country was divided into a Communist North Vietnam (Democratic Republic of Vietnam-DRV) and a pro-Western South Vietnam (Republic of Vietnam). The North's attempt to establish a socialist state on its territory led to the first refugee wave to the South (1954-1956) (UNHCR 2000; Weggel 1997: 165). As in many other countries during that period, the Cold War was going on in Vietnam as well-North against South. The Vietnam War (19601975), triggered by the military support of the United States (US) for the antiCommunist South, formed the peak of this conflict. After the signing of the Paris Peace Accords in 1973, the United States withdrew from Vietnam, but the internal war continued until 30 April 1975, when the Communists conquered Saigon. ${ }^{1}$ The fall of Saigon caused US collaborators and members of the overthrown government of the Republic of Vietnam to leave the country. In July 1976, Vietnam was reunified as the Socialist Republic of Vietnam (SRV; Cộng hòa xã hội chủ nghĩa Việt Nam) (UNHCR 2000). From that time on, the aim of the Communists was to establish socialism in all areas of life (Lulei 2000: 101). According to Weggel (1997: 167), the transformation process consisted of various programmes like the resettlement of urban people into the New Economic Zones. In the view of Engelbert, Lulei, Suryadinata and the United Nations High Commissioner for Refugees (UNHCR), these programmes were indeed directed against the Hoa (as well as against other ethnic minorities) and put them under pressure (Engelbert 2002: 621, 617-625; Lulei 2000: 102; Suryadinata 1985: 45-46; UNHCR 2000; Will 1988: 177). Consequently, the first Hoa left North Vietnam in 1978, aiming for Dōngxīng 东兴, a town on the border of China in the province of Guăngxī 广西, and within one month 20,000 Hoa had already left. This marks the beginning of a mass exodus, which continued until 1979 (Engelbert 2002: 623).

1 In parallel, Soviet-style socialism also gained ascendancy in Cambodia and Laos. 
In the meantime, Sino-Vietnamese relations deteriorated and resulted in the 'punishment expedition," (Strafexpedition; according to the Chinese leadership, 'to teach Vietnam a lesson' (jiàoxùn yuènán 教训越南)) (Engelbert 2002: 623-626). This incident marked the absolute low in the relationship between the two states, for which the causes are diverse and complex. Engelbert emphasises that these causes have to be differentiated between the north and the south of Vietnam. China's proximity meant that in the north the Hoa were viewed as possible collaborators and therefore as a threat to national security. In the south, the Chinese minority was mainly occupied with business and trading and had connections to the old regime and became victims of the socialist reformation. Furthermore, the perception of the Hoa in the eyes of the Vietnamese was influenced by their privileged status during French colonial times, resulting in their image as a risk to national stability (Engelbert 2002: 633-634). Suryadinata shows that ethnic Chinese in Southeast Asia have generally been seen as a threat as they not only represented the biggest ethnic minority in this region, but also occupied key positions in the economy. Additionally, the PRC has always encouraged the image of a superpower that sought regional hegemony (Suryadinata 1985: 7).

In this study I will identify the circumstances and factors that triggered the mass exodus out of North Vietnam at the end of the 1970s, and focus on the Hoas' perception. Some migration and refugee researchers point to the issue of attributing a passive role to refugees (Nicholson and Twomey 1999: 3; Binder and Tosic 2002: 6). In order to avoid this problematic approach, my arguments pursue the following questions: what were the Hoas' motivations for leaving Vietnam? What were the push and pull factors? In a second step I question why they chose to continue their flight to Hong Kong and Austria as places of resettlement. I make the proposition that even forced migrants do take decisions independently and act in self-determination.

So far there are not any data available that could be used for filtering the push and pull factors for the Hoa in leaving North Vietnam and resettling in Austria. I decided therefore to create a qualitative questionnaire along the lines of the qualitative guided interview (qualitative Leitfadeninterview) by Lamnek (2005) and based it on the theory provided by Han (2000), who established a 'five phases model' (Fünfphasenmodell). He posits that every migrant goes through five steps of consideration until he/she takes the decision to leave a country because of dissatisfaction with the present situation and to relocate to another country chosen for its future hopes of a better life and advanced access to resources, especially in terms of the labour market and education. Although Han's conception is based on voluntary migration, it still offers a suitable instrument for my study of forced migration, as even refugees go through a decision-making process. Han, Lucassen and Opitz also conclude that a differentiation between voluntary and forced is not recommended be-

2 All translations in this article have been made by the author, if not stated otherwise. 
cause of the complexity of migration (Han 2000: 13; Lucassen and Lucassen 1999: 14-21; Opitz 1997: 11). As mentioned above, Han's 'five phases model' describes the individual's confrontation with migration as a process of five phases defined as follows: social circumstances, establishment of a motive, search for information, readiness to assume risk, and decision (Han 2000: 171-178). In the first phase, the individual finds himself in an unsatisfactory situation of burdensome social circumstances, which he/she is powerless to change (e.g., political constellations). Han calls these 'social push factors'. In the second stage, the person becomes aware that migration is not just a potential solution to the unsatisfactory situation, but also connects certain hopes with it, the realisation of which seems to be feasible (Han 2000: 171). In the third phase, the individual deals with the choice of destination by getting information and evaluating it; family, relatives and friends often play a crucial role in this stage. The associations that the person has with the destination are rarely based on reality, but are equally important for the decision. During the fourth phase, the individual gradually develops a readiness to take the risks that migration involves. Han points out that some migrants do not develop this willingness, depending on whether they personally do or do not desire to leave the country (Han 2000: 176). In the fifth phase, the decision to migrate is finally made, with family and friends playing a significant role in the decision. With this last phase, preparation is finalised and migration will be realised. Han notes that in reality discrepancies from the 'five phases model' may occur, as decisions to migrate are not always taken in a mood of rationality (Han 2000: 177).

I would like to note that adhering to the methods of Lamnek's qualitative guided interview and Han's 'five phases model' (see above) in creating the questionnaire gave me the necessary means to ensure distance during the whole research process, despite my personal connection to this topic. ${ }^{3}$ But then again, it also turned out to be an advantage to be 'part' of the group of Hoa living in Austria, because of sharing the same language and gaining their openness during interviews. In total, six people were interviewed (identified as Persons 1-6), whom I chose according to the following criteria: Hoa from North Vietnam, who should have been adults during the time of leaving the country, to ensure self-determination and self-consideration. The interviews were carried out in Cantonese, which is the second mother tongue of the Hoa after Vietnamese. Transcription of the interviews was done firstly in Cantonese and then translated into Chinese standard language. After summarisation I adapted the material to Han's 'five phases model'. Generally, motivations to migrate consist of multiple factors (Han 2000: 13). On the one hand, exogenous circumstances trigger migration, but on the other hand, subjective opinions and calculations influence the decision of the individual. E. G. Ravenstein's 'gravitation model' (Gravita-

3 I would like to remark that my parents were themselves part of this group of Hoa who left North Vietnam at the end of the 1970 s. 
tionsmodell) tries to ensure this complexity by classifying push and pull factors. Push factors are situations in the home country which give motivation for migration, while pull factors are circumstances in the destination country, which appear as stimulation (Han 2000: 13-14). Basing myself on this model I filtered the push and pull factors; at the same time single factors were ranked according to the frequency of occurrence, differences and similarities were identified and secondary literature was consulted wherever required to gain a deeper understanding of the interactions between the various motives. ${ }^{4}$

During the research process the following complexity showed up: four interviewees fled to the PRC (step 1) before they reached Macao or Hong Kong (step 2) and resettled in Austria (step 3). For reasons of clarity I call them 'Group 78', as they left Vietnam in 1978. In contrast, the two other interviewees migrated directly from North Vietnam to Macao or Hong Kong (step 1) and reached Austria afterwards (step 2). This is 'Group 79', who started their journey in 1979 (see table 1).

Table 1: Differences between 'Group 78' and 'Group 79'

\begin{tabular}{|l|l|}
\hline Group 78 & North Vietnam $\Rightarrow$ PRC $\Rightarrow$ Hong Kong/Macao $\Rightarrow$ Austria \\
\hline Group 79 & North Vietnam $\Rightarrow$ Hongkong/Macao $\Rightarrow$ Austria \\
\hline
\end{tabular}

This definition conforms with Engelbert's, who also classified the mass exodus of the Hoa into a first (1978) and second phase (1979), on the one hand because of the different migration routes and on the other hand because of the different causes. Whereas the Hoa left the country by land in 1978, those from 1979 had to take the sea route. Furthermore, Engelbert believes that the first phase was provoked by the PRC, whereas the second phase was caused by the Vietnamese leadership through forced relocation of the Hoa into the New Economic Zones, the focus of which was to gain 'a more even distribution of population, land reclamation, elimination of unemployment in the cities, improvement in national defence and the institutionalisation of a new division of labour'5 (Engelbert 2002: 625-626). Indeed, both groups did take different routes to leave the north, but the interviews done with the Hoa

4 Please note that for reasons of simplification and protection of anonymity, male pronouns refer to both male and female interviewees.

5 '[...] gleichmäßigere Bevölkerungsverteilung, Neulandgewinnung, Beseitigung der Arbeitslosigkeit in den Städten, Verbesserung der Landesverteidigung und Institutionalisierung einer neuen Arbeitsteilung.' 
living in Austria may only partly confirm if the mass exodus was initiated firstly by the PRC and then by the SRV, as we will see in the course of this study.

\section{Results: Hoa motivations in leaving North Vietnam}

\section{Páihuá: the most significant push-factor}

The Hoa had the following motivations to leave North Vietnam: they were pushed on the one hand by the Vietnamese páihuá policy at that time and on the other by the mutual influence of family, relatives and friends. Páihuá, a term extracted from the interviews done with the Hoa who resettled in Austria, is the abbreviated form for páichì huárén 排斥华人 and can be translated as 'displacement of ethnic Chinese'. Páihuá is defined as a discriminative policy of the Vietnamese leadership aimed at disadvantaging ethnic Chinese especially in terms of access to higher education and within the labour market (Persons 1-6, 2006). They described the situation as follows: no admission to university, no equal access to the labour market and no permission to work in the private sector. ${ }^{6}$ As the situation deteriorated, the Hoa were refused any kind of jobs (Persons 1 and 2, 2006), ${ }^{7}$ were partly excluded from food distribution (Persons 3 and 4, 2006) and became victims of verbal attacks (Person 1, 2006). These circumstances not only made life for the Hoa in Vietnam significantly difficult, but created also a fear of further worsening in the anti-Chinese policy without knowing how far the deterioration would go, not only for themselves but also for following generations (Persons 1, 3, 4, 2006). It has to be mentioned that páihuá affected not only the Hoa, but also those ethnic Vietnamese who were married to Hoa and therefore, were also victims of discrimination (Persons 3, 5 and 6, 2007). Furthermore, the Hoa were not allowed to hold any political office.

Opitz identifies the causes for mass exodus in the Third World within internal and international conflicts. He points to three important developments: the process of decolonisation, the East-West conflict or Cold War, and the emergence of new nation states (Opitz 1997: 18). Following this theory, the causes for the appearance of páihuá will be defined from a historical, a foreign political and a domestic perspective. Additionally, the perspective and the role of the Hoa have been included as a fourth dimension in order to counter the concept of refugees as passive actors.

6 It should be mentioned that after reunification, Vietnam went through a socialist reformation, which involved negation of the private sector. This might not necessarily have been aimed against the Hoa, but as ethnic Chinese were mainly active in the private sector they were hit quite hard by the socialist reformation. In order to protect the interviewees' anonymity, the term 'person' is used instead of their names. 


\section{Historical aspect of the páihuá phenomenon}

The historical research shows that the relationship between the Vietnamese leadership and the ethnic Chinese has always been ambivalent. On one side, the Hoa were needed for their economic abilities and their networks to countries outside of Vietnam, but on the other side they were considered as a threat to national stability, as the Vietnamese leadership has always questioned their loyalty (Engelbert 2002: 130134). During colonial times in Vietnam (1859-1945) the Hoa received preferential treatment by the French. The colonial rulers recognised the role of the ethnic Chinese for the economy and deliberately used the "principal of "divide et impera" in order to weaken anti-colonial tendencies within Vietnamese society by attracting the hatred of the indigenous people on to the Hoa (Opitz 1988: 42). Nevertheless, it has to be pointed out that specific areas were reserved as monopolies for the French only. Through their privileged position, many of the Hoa achieved prosperity and wealth exactly under circumstances that enlarged the gap between themselves and the natives. In addition, the assimilation process was hindered by a migration wave lasting from 1880 to 1929 . In contrast to past immigrations dominated by men, this wave brought a lot of Chinese women to Vietnam, which according to Engelbert advanced the preservation of Chinese identity, but at the same time hindered integration (Engelbert 2002: 276; Möller 2005: 31). After decolonisation, French preferential treatment of the ethnic Chinese continued to have an effect on the perception of the Vietnamese and was thus a breeding ground for a páihuá-style political line.

December 1946 marked the beginning of the Vietnamese-French war, also known as the First Indochina War. During that time, the Nationalist Guómíndăng 国 民党 government was only interested in the protection of the overseas Chinese population in Vietnam. In return, anti-French campaigns were forbidden in China. However, the Communist victory in China in 1949 constituted a turning point: from that time on the Việt Minh ${ }^{8}$ received military support not only from the Union of Soviet Socialist Republics (USSR), but also from the PRC in the war against the French. At this point, the US stepped into the Indochina War with the argument of the domino theory, which predicted the Asian region would fall more and more into the Soviet sphere of influence, a development that in their eyes had to be prevented. The expansion of the Indochina War from a regional into an international affair, Engelbert argues, 'had consequences for the perception of the Chinese and for the concrete policy towards the Chinese minority in Indochina on the part of the Americans, the French and the Vietnamese" ${ }^{9}$ (Engelbert 2002: 458). From that time on, the

8 Abbreviation for Việt Nam Độc Lập Đồng Minh Hội, which means 'League for the Independence of Vietnam'.

9 'Auch Folgen für die Wahrnehmungen der Chinesen und für die konkrete Politik gegenüber der chinesischen Minderheit in Indochina durch Amerikaner, Franzosen und Vietnamesen.' 
Hoa were perceived as a threat with the potential to form China's 'fifth column'. 10 The French in particular feared Communist manipulation of the ethnic Chinese (Engelbert 2002: 459-460). However, according to Engelbert, the latter could not be influenced either by the French or by the Việt Minh (Engelbert 2002: 501). As a result of the Geneva Conference in 1954, Vietnam was separated along the 17th latitude into the Democratic Republic of Vietnam in the North and the Republic of Vietnam in the South, resulting in two independent states (Engelbert 2002: 308-309, 447-504; Sembdner 1978: 32-33). Vietnam stayed divided until 2 July 1976. Sembdner talks about the ambition of the DRV to enhance the integration of the Chinese minority into Vietnamese society (Sembdner 1978: 143). But Engelbert's illustrations show us another picture: during that period a series of campaigns had been carried out that can be classified as anti-Hoa. Here, Engelbert sees the specific causes for the mass exodus of the Hoa:

The potentials for conflict emerged not only in the year 1978. At this point, a historical return to the period from 1950 until 1973 seems necessary to be able to understand why the majority of the Hoa who lived in the north of Vietnam before 1978 left the country from 1978 until 1979 (Engelbert 2002: 617). ${ }^{11}$

\section{Foreign politics: the role of the PRC}

The páihuá phenomenon in the context of Vietnam's foreign policy shows that especially during the 1970 s, relations between the PRC and the recently unified Socialist Republic of Vietnam deteriorated gradually; the mass exodus of the Hoa from 1978 to 1979 and the PRC's 'education campaign' (Erziehungsfeldzug) against the SRV may be marked as the highlight of the conflict. After the foundation of the PRC in 1949 the Chinese leadership was close to the USSR and viewed the United States as the biggest enemy, until the ideological break in the mid-1950s between the Soviet and Chinese leaderships, which changed the situation substantially. At the same time, relations between the PRC and the US gradually normalised towards the end of the 1970s (Kempf 2002: 1-2), which aroused suspicion among the Vietnamese leaders (Engelbert 2002: 631; Suryadinata 1985: 54). According to Suryadinata's estimation, after Sino-Soviet relations deteriorated, and with publication of the Soviet Brezhnev doctrine, the PRC considered the USSR as a bigger threat than the US (Suryadinata 1985: 28-29; Zhou 2004: 136). As a consequence, the PRC sought to draw close to the US in a refusal of Soviet hegemonic attempts in Southeast Asia. 'In April 1975 the forcible reunification of Vietnam under Hanoi's leadership

10 See the explanation of this term below.

11 'Die Konfliktpotentiale entstanden nicht erst im Jahre 1978. An dieser Stelle erscheint ein historischer Rückgriff auf die Periode von 1950 bis 1973 notwendig, um verstehen zu können, warum die Mehrzahl der Hoa, die vor 1978 im Norden Vietnams lebte, das Land von 1978 bis 1979 verließ.' 
strengthened China's fear of a gradual replacement of US imperialistic supremacy by the USSR ${ }^{12}$ (Möller 2005: 91). Besides, it seemed that a solution of the Taiwan issue enjoyed priority in China's foreign policy. In December 1978, the PRC and the US issued a 'Joint Communiqué on the initiation of diplomatic relations between the PRC and the USA', which shows that the main motive of the Chinese leadership consisted in recognising the US as a legitimate state and in ensuring that Taiwan belonged within its sphere of influence (Zhou 2004: 143). Furthermore, the Vietnamese thought that the Chinese leadership favoured a division of Vietnam in order to be able to follow their attempts at expansionism and hegemony in Indochina. The SRV assessed that not only was the closeness between the PRC and the US evidence for this, but also Chinese resistance to interstate relations between the SRV and especially the USSR and other socialist states. In Vietnam's eyes, therefore, China would like to prevent the SRV from becoming powerful and following an antiVietnamese policy (Zhōngguó zhànyǒu liánméng 1979). In contrast to the PRC, the SRV considered the US, not the USSR, as the biggest enemy (Suryadinata 1985: 44). Furthermore, the PRC was viewed not only by the SRV but also by other countries in the Southeast Asian region as a threat on account of its size and traditional relations (Bolt 2000: 108). Hence, according to Dohmen, two opposite poles emergedon the one hand the USSR and the SRV (Laos was also part of this group), and on the other hand the PRC and the US (with Cambodia as an unofficial member): 'For this reason it becomes clear that the conflict between Hanoi and Peking has more than just a regional framework, but has in the meanwhile acquired world political dimensions ${ }^{, 13}$ (Dohmen 1978: 430).

It was possible to identify many controversies between the two states, as well as likely causes. During the time that the PRC considered the USSR as its biggest opponent and approached the US, the SRV evaluated the US as its bitterest enemy and tied itself closely to the USSR. We may therefore conclude that the Sino-Vietnamese conflict was inherited from the history between the two states and related to other controversies, an extension of the Cold War between the USSR and the US into the Asian region. In this sense, the dispute over the Hoa resulted from rather than caused the controversies between the PRC and the SRV. In fact, both countries used these controversies for propaganda purposes. While the Chinese side accused the Vietnamese government of intentionally displacing the Hoa, the Vietnamese side blamed the Chinese leadership for initiating the mass exodus of the ethnic Chinese by mixing 'subversive elements' within the Hoa and designated the Hoa as a fifth column (dìwǔ zòngduì 第五纵队) to destabilise Vietnam (Zhōngguó zhànyǒu liánméng

12 'Im April 1975 bestärkte die gewaltsame Wiedervereinigung Vietnams unter Führung Hanois Chinas Befürchtungen vor einer allmählichen Ablösung der USA als imperialistische Vormacht durch die UdSSR.'

13 'Damit wird deutlich, dass der Konflikt zwischen Hanoi und Peking mehr als nur einen regionalen Rahmen, sondern inzwischen weltpolitische Dimensionen gewonnen hat.' 
1979). The term 'fifth column' originated from the Nationalist general Emilio Mola Vidal during the Spanish Civil War (1936-1939), when he named his loyal supporters in the opposite camps in Madrid as such, whereas four of his army columns were marching with him towards Madrid. Thus, the term describes a group of subversive elements within a country who are loyal to another power and work against local authorities:

\begin{abstract}
A cardinal technique of the fifth column is the infiltration of sympathizers into the entire fabric of the nation under attack and, particularly, into positions of policy decision and national defense. From such key posts, fifth-column activists exploit the fears of a people by spreading rumours and misinformation, as well as by employing the more standard techniques of espionage and sabotage (Enyclopaedia Britannica 2011).
\end{abstract}

In the 1970s the Hoa were increasingly designated as a fifth column and denounced as the 'tools' of the PRC by the Vietnamese leadership. Such an accusation was not groundless, as Möller shows that the PRC had been using the foreign policy strategy of a 'United Front from below' (Einheitsfront von unten), which was marked by the separation of national and party relations (Möller 2005: 96-97). According to Kempf, such perceptions on the part of Vietnam (and also of Southeast Asia) were influenced by the fact that after its foundation the PRC supported revolutionary movements opposing the local governments of Southeast Asian countries. Kempf assumes that the loyalty of overseas Chinese was often questioned because of their economic strength and dominance in the region (Kempf 2002: 112, 116; Bolt 2000: 109-110). Bolt points out furthermore that the Chinese government was following an ambiguous policy towards the overseas Chinese: 'Chinese abroad were called to be patriotic and contribute to the Four Modernizations. At the same time, they were also encouraged to choose local nationality' (Bolt 2000: 109). However, the question remains whether the Chinese leadership was able to or intended to guide the Hoa idelogically and politically. The Vietnamese White Paper claims that the mass exodus of the Hoa was caused by ethnic Chinese organisations influenced by the PRC (Zhōngguó zhànyǒu liánméng 1979). In contrast, Suryadinata and Dohmen think that the refugees became a financial and economic burden to the PRC (Suryadinata 1985: 49; Dohmen 1978: 427). Dohmen explains that the PRC indeed tried to attract overseas Chinese, who were to bring investment and the necessary know-how to establish the country, but as the majority of Hoa refugees from North Vietnam were workers and craftsmen they were not able to fulfil these demands. Furthermore, they were mainly occupied in the private sector in urban areas, which led to employment problems (Dohmen 1978: 427). Four of the six interviewees fled to the PRC first before they reached Hong Kong or Macao. Only one of the four considered China as a transition country from the beginning (Person 2), while two of them were not satisfied with working in the state-owned farms for overseas Chinese- the huáqiáo nóngchăng 华 侨农场一 as they were not familiar with farming. Later on, this became a push factor 
for them to leave the PRC again (Persons 4 and 6, 2006). The fact that the Chinese authorities did not hinder the Hoa from leaving China, by pretending not to have noticed them leaving for Hong Kong or Macao (Person 2, 2006), seems to confirm that the Chinese government was itself overburdened by the situation of the mass refugees. One Hoa reports disappointedly that 'in fact, too many returned, China was not able to cope with the situation and placed all of them into the state-owned farms ${ }^{14}$ (Person 4, 2006). One might argue that economically it would not have been of any advantage to the Chinese leadership to use the Hoa in Vietnam as a fifth column and to trigger a mass exodus into their own country. Furthermore, as soon as the Hoa departed, they would not have been able to fulfil the intention of a fifth column, namely, practising political subversion within the 'enemy'. Labelling the Hoa as a fifth column suggests that the Vietnamese side was not only expressing its mistrust of the Hoas' loyalty, but was also boosting its propaganda against the PRC and justifying its páihuá policy.

The question of whether the Hoa were loyal to the PRC or not in order to fulfil the role of a fifth column is a complex topic and is primarily related to their identity, which is itself influenced by many factors. Hence, this aspect may only be touched on marginally in this study. In this context Suryadinata emphasises that, seen ideologically, the ethnic Chinese are relatively heterogeneous and we may not therefore assume that they are all 'pro-PRC communist' (Suryadinata 1985: 22). Engelbert's analysis shows that only a few Hoa student organisations in Vietnam got enthusiastic about Chinese communism and we may not speak about 'mobilisation'. On the contrary, most of the Hoa in Vietnam were (or rather, still are) doing business and have rarely had a positive attitude towards socialism (Engelbert 2002: 459-467). Research done by Suryadinata results in a similar picture. He also points to the difficulty of proving connections between overseas Chinese and the Communist party, due on the one hand to insufficiency of information and on the other to the fact that Communist organisations in Indochina mainly consist of indigenous members (Suryadinata 1985: 19). 'Overemphasis regarding ethnic Chinese involvement in communist parties tends to obscure the fact that there are also many militant anticommunist Chinese' (Suryadinata 1985: 21). Furthermore, 'political ideology and culture are not the same; the ethnic Chinese may be interested in the culture but not necessarily in the communist ideology' (Suryadinata 1985: 141; Bolt 2000: 119). Referring to the interviewees, they see themselves as Chinese (中国人 zhōngguórén), consider China as their fatherland and sometimes participate in pro-Chinese movements in Vietnam (Person 4, 2006), but on the other hand they define themselves as anti-Communist as they developed a negative perception of this ideology after having witnessed the socialist transformation in Vietnam. One interviewee describes the

14 'Shí zai huí qù dàlù tài duō le, zhōngguó jiějué bú dào, quánbù dōu fàng zài nóngchăng.' 实在回去大陆太 多了, 中国解决不到, 全部都放在农场. 
Hoa's identity most accurately: 'We are stateless...Mainland China says we are Vietnamese; Vietnam says we are mainland Chinese" ${ }^{15}$ (Person 6, 2006). The Hoa mainly adopted an anti-Communist stance and could not be manipulated as a fifth column by an outside power. Even though there were some individuals who sympathised with the socialist ideology of the PRC during that time, they still did not have the potential to cause a mass exodus (as the Vietnamese side liked to describe). Suryadinata concludes:

It appears that the exodus was largely caused by Hanoi's policy towards the ethnic Chinese and the Sino-Vietnamese tension which was building up gradually. Hanoi was suspicious of the PRC and regarded all ethnic Chinese as pro-Beijing and hence decided to get rid of them for political and security reasons (Suryadinata 1985: 49).

Although the Chinese leadership did not have the power to manipulate the Hoa ideologically, they were able to influence the decision on the destination of some Hoa in northern Vietnam by a very positive self-presentation in the media: 'Vietnam displaces and China talks well: if you return, if you lived in the city, then China will let you go into a city; no matter which area of business you were working in [author's note: in Vietnam], you will be able to work in the same area [author's note: in China) ${ }^{16}$ (Person 4, 2006). It seems that the PRC did not intend a mass exodus to its own country because of financial and economic constraints, but it showed a positive attitude towards a 'return' of the Hoa, mainly for propaganda purposes. Nonetheless, the Chinese leadership thereby created a pull factor for the Hoa to aim at the PRC as their country of destination. It seems that although the Hoa were mainly antiCommunist and apolitical, Group 78 was initially still convinced that migrating to the PRC was the only logical conclusion: 'Besides, we are also Chinese, except for China we have nowhere else to go. We did not have another way at all. China was the nearest, we were only able to go to China. We could not go to any other places, 17 (Person 1 2006). Of course the geographical proximity to China also played an important role for security reasons. Furthermore, according to an UNHCR report, the PRC was indeed the only nation in the Asian region granting asylum to the refugees and initiated a programme to locate them in state-owned farms (UNHCR 2000). Still, it has to be mentioned that obviously the emphasis on their 'Chineseness' by both

15 'Wǒmen shì méi yǒu guójiā de rén...Dàlù shuō wǒmen shì yuènán rén, yuènán shuō wǒmen shì dàlù rén.' 我们是没有国家的人…大陆说我们是越南人, 越南说我们是大陆人.

16 'Yuènán pái, zhōngguó shuō hăo de dōngxi: nǐ huílái, rúguǒ shì zhù zài chéngshì de, tā ràng nǔ qù chéngshì; nǐ zuò shénme hángyè tā jiù gěi nǐ zuò shénme hángyè.' 越南排, 中国就说好的东西: 你回 来, 如果是住在城市的, 他让你去城市; 你做什么行业他就给你做什么行业.

17 'Érqiě wǒmen yě shì zhōngguó rén ma, chú le zhōngguó y̌̃ wài wǒmen dōu méi shénme dìfang hăo qù. Gēnběn dōu méiyǒu dì èr tiáo lù kéyǐ zǒu, zhōngguó shì zuì jìn de, wǒmen zhǐ néng qù zhōngguó. Bié de difang dōu bù néng qù.' 而且我们也是中国人嘛, 除了中国以外我们都没什么地方好去. 根本都没有第 二条路可以走, 中国是最近的, 我们只能去中国. 别的地方都不能去. 
the Vietnamese and the Chinese leadership intensified the push and pull factors and motivated them to choose the PRC as a destination, at least in the first phase of the exodus.

The páihuá phenomenon in an internal political context: the 'politicisation of ethnicity' in the course of the establishment of a 'nation state'

Suryadinata traces the local adverse sentiment against China back to the establishment of nation states in Southeast Asia - a process which started after decolonisation following World War II: 'The process is by no means smooth, especially in some countries where the government requires complete eradication of "Chineseness", (Suryadinata 1985: 23). In general, ethnicity includes cultural characteristics and attributes like language and traditions, but also individual identity. Two trends exist to date. The primordial perception describes ethnicity as given by nature; the ethnic descent and same historical past and culture include an individual in an ethnic group, implying that ethnicity is non-changeable. Social constructivists see ethnicity as flexible, as it only develops through individual interaction with a community, implying an individual choice of belonging to specific ethnic groups (Cohen 1999: 4; Dittrich and Lentz 1995: 25, 27-28; Kößler and Schiel 1995: 2-4; Bolt 2000: 19, 21). Smith notices that most researchers agree that nations and nationalism are phenomena of modernity, but there are also primordialists who consider nations as hereditary to human nature (Gellner 1999: 32).

By placing the páihuá phenomenon in the context of Vietnam's internal political situation we meet with the politicisation of ethnicity in the course of the emergence of a nation state after decolonisation. A nation state recognises itself as a closed territory whose citizens are connected by a collective past, common ancestors and culture (Smith 1999: 38). Smith differentiates the concept of a state from that of a nation, defined by its institutions within an isolated area. Nationalism, which emerged after the French Revolution, is defined as an ideologically motivated movement focusing on maintaining unity and pointing to a shared identity of the people, especially in terms of establishing a nation (Smith 1999: 37-38; Fine 1999: 154). Smith, MacCormick and Fine identify two different types of nationalism, civic and ethnic. Civic nationalism is characterised by the joint maintenance of governmental institutions and respect of law and order. Anybody who upholds these principles may be part of the nation. In contrast, ethnic nationalism builds on joint descent and a common culture formed by history (MacCormick 1999: 126; Smith 1999: 41). Fine thinks that "the basic difference between "ethnic" and "civic" forms of nationalism is that in the latter case it is the state which defines the nation, while in the former it is the nation which defines the state' (Fine 1999: 152). The mass exodus of the Hoa from 1978 to 1979 can be put into the context of an emerging Viet- 
namese nation state and an arising of an ethnic nationalism, where ethnicity became a political tool (Kößler and Schiel 1995: 1). Kößler and Schiel emphasise the inclusive character of ethnicity as focusing on commonalities and coherence, whereas the exclusive character underlines the displacement and exclusion of specific groups (Kößler and Schiel 1995: 5). After decolonisation, the Vietnamese leadership had to prove its legitimacy by instrumentalising homogenisation-a collective Vietnamese identity had to be established, which politicised ethnicity (Kößler and Schiel 1995: 17; Dittrich and Lentz 1995: 37; Opitz 1988: 51-52; Opitz 1997: 22-23). Additionally, 'the privileging of the Chinese was felt more strongly by the Vietnamese nationalist elites after 1954 than it really was ${ }^{18}$ (Engelbert 2002: 280). Thus, ethnic nationalism used the argument of ethnicity as a political instrument in order to secure access to positions associated with power for those having a place within the Vietnamese identity and granting them rights and entitlements, while excluding the Hoa from 'Vietnamese-ness' through discrimination for reasons of separatism, which the ethnic Chinese were accused of.

\section{One more push factor: family and friends}

Another motivation for the Hoa to leave North Vietnam was the push factor: influence by family, relatives and friends. It turned out that the information flow within the Hoa community was a strong factor in accelerating migration. Awareness of those deciding to leave the country was often enough to create unrest among the ethnic Chinese in such a way that they started considering migrating themselves. 'However, in reality such a rational approach is not the rule. Family members or friends often play a central role as a source of information. On many occasions their information and arguments are more significant than rational and logical arguments' ${ }^{19}$ (Han 2000: 175). Han also points out that this phenomenon usually emerges as soon as migration procedures become something like mass movements. In situations like these one's own motivation becomes unimportant, while the migration model of others becomes much more significant (Han 2000: 26): 'Sometimes we did not need to discuss. If one family left, the second would follow; there was no need for motivation. Anyway, if you were overseas Chinese you would have to (de-

18 'Die Privilegierung der Chinesen von den vietnamesischen nationalistischen Eliten nach 1954 nachdrücklicher empfunden wurden, als sie in Wirklichkeit war.'

19 'In der Realität ist jedoch eine solche rationale Vorgehensweise nicht die Regel. Oft spielen Familienangehörige oder Bekannte als Informationsquelle eine zentrale Rolle. Ihre Informationen und Argumente sind häufig bedeutsamer als rationale und logische Argumente.' 
cide to) leave ${ }^{20}$ (Person 4, 2006). Up to the end of 1979 more than 250,000 Hoa left for the PRC (UNHCR 2000).

\section{The pull factor of freedom: opting for Hong Kong}

The interviewees show us that life in the state-owned farms was not easy for them as they were not used to physical work. They were also disappointed, as they were not aware of the fact that they would be placed in these farms once they arrived in the PRC (Persons 4 and 6, 2006). In fact, most of Group 78 did not plan to leave the PRC, but the information flow among the Hoa awakened their awareness of the possibility of migrating to Hong Kong: 'Actually, we decided to stay...suddenly I heard that there was a refugee camp in Hong Kong. We all of us only followed the masses. We heard that Hong Kong is free,21 (Person 1, 2006). Consequently, this factor became a pull factor too. Only one interviewee considered the PRC as a transit country even before leaving the SRV: "I just "borrowed" the way via China because it was very difficult to get to Hong Kong from Vietnam'22 (Person 2, 2006). As mentioned by the interviewees, the unsatisfactory circumstances in the PRC were lack of democracy and human rights, a similar political system as in the SRV and low incomes (Persons 1-6, 2006). The pull factors for Groups 78 and 79 differ insofar as Group 79 had the additional information from Hoa who had already migrated that there was the possibility of reaching the refugee camps in Hong Kong. This raised positive associations of not only entry to a free and better life compared to the circumstances in Communist China, but also the strong confidence that the latecomers might manage to get there as well. Keeping this in mind, we may conclude that the migration flow of the Hoa developed its own dynamic, directed by an effective information network. While the pioneers of Group 78 chose the PRC as a destination for the first stage, Group 79 already knew that the refugee camps in Hong Kong and Macao were the better choice. Weggel assumed that the PRC 'suddenly' closed its borders as they were economically unable to cope with the mass of refugees, and the Hoa became 'boat people' for this reason (Weggel 1997: 173). This point cannot be verified by Group 79; rather, they mentioned poverty and a lack of future prospects in the PRC and the help of the UN in the refugee camps of Hong Kong and Macao as reasons for no longer choosing the PRC as their destination (Persons 3 and 5,

20 'Yǒu shíhou dōu bú yòng tăolùn. Yí gè jiātíng zǒu le, dì èr gè jiātíng yě gên zhe zǒu; dōu bú yòng yùndòng nĭ. Zǒngzhī shì huáqiáo, jiù dăsuan yào zǒu le.' 有时候都不用讨论. 一个家庭走了, 第二个家庭也跟着 走; 都不用运动你. 总之, 是华侨就打算要走了.

21 'Běnlái wǒmen juédìng liú xià lái...tūránjiàn tīngdào xiānggăng yǒu nàn mín yíng. Wǒmen dà jiā zhĭ shì lā duì zŏu de. Wǒmen dōu tīngshuō xiānggăng zì yóu.' 本来我们决定留下来...突然间听到香港有难民营. 我们大家只是拉队走的. 我们都听说香港自由.

22 'Wǒ zhĭ xiăngdào zhōngguó jiè lù, yīnwèi cóng yuènán qù xiānggăng hěn nán.' 我只想到中国借路, 因为 从越南去香港很难. 
2006). One interviewee from Group 78 even reported that the Chinese leadership did not create difficulties for the Hoa in leaving the PRC: 'The Chinese government did not care about these overseas Chinese. They knew we were seeking freedom. They turned a blind eye, they did not care about us ${ }^{23}$ (Person 2, 2006). Both Groups 78 and 79 chose the sea route to reach the destinations of Hong Kong and Macao. Two interviewees explained that they left the PRC via Běihăi 北海, at that time a popular port for starting the journey (Persons 1 and 2, 2006). One Hoa argued that he had to take the more dangerous sea route instead of the land route as he was aware that Hong Kong and Macao only accepted refugees from Vietnam. Hence, we may assume that most of Group 78 chose to reach the UN camps by boat in order to fulfil the conditions of being considered as refugees, and they acquired fame as boat people.

\section{The implied pull factor: Austria as the final destination}

Analysing the push and pull factors that had an influence on the Hoas' decision to migrate to Austria, it has to be concluded that there were not any, except for one interviewee. The reasons for the lack of pull factors can be found within the circumstances of the refugee camps, which brought about a loss of self-determination on the part of the Hoa. In the process of 'dematuration', the emphasis is on the bureaucratic organisation of the camps, which creates dependency among the refugees and leads to the assumption on the part of the camp management that a refugee is not capable of making his or her own decisions, and hence will be reduced to the role of a passive and helpless child (Domanski 1994: 22-23; Chan and Loverdige 1987: 753; Inhetveen 2006: 8):

'Dematuration' begins with the transference of the decision-making from the refugee to officials and with the assuming by the latter of the right to intrude into the private world of the former. Dependence on bureaucratic arrangements, coinciding with a lack of options for attaining even modest self-sufficiency, creates a sense of personal inefficacy, lack of power and self-determination. A person is reduced to the role of a 'child' incapable of managing his/her own affairs, who can be controlled, patronized and even scolded (Domanski 1994: 23).

Asked for their motivation in migrating to Austria, the Hoa indicated mainly reasons that were imposed on them from the outside; Austria was willing to accept them, and further organisation was left to the UNHCR.

23 'Zhōngguó de zhèngfǔ bù lì nà xiē huáqiáo. Tāmen zhīdào wǒmen shì zhăo zì yóu de. Tāmen yì yăn kāi yì yăn bì de, bù lǐ wǒmen.' 中国的政府不理那些华侨. 他们知道我们是找自由的. 他们一眼开一眼闭的, 不理我们. 
In view of the Vietnamese mass exodus of 1978 and 1979, a conference was convened in Geneva in 1979 in order to find a way to cope with the refugees. In fact, the Western developed countries agreed to accept them. Quotas and criteria for acceptance were determined by the individual countries, and representatives were sent to the UNHCR refugee camps to make a selection. Hans and Suhrke (1997: 101) have shown that 'the market system of resettlement was reasonably successful in finding compatibility between the needs of the receiving countries and refugees.' However, since the flood of refugees did not stop until the end of the 1980s, the Western developed countries in the end were not willing to accept any more refugees from Vietnam. In 1989, a Comprehensive Plan of Action (CPA) was therefore prepared. From that time on, the refugee status of each individual had to be verified according to the criteria of the Geneva Convention (Hans and Suhrke 1997: 100-101; UNHCR 2001; Weggel 1997: 169-170). In this sense Hans and Suhrke assume that acceptance of refugees was guided by the following points:

(i) legal and humanitarian concerns, (ii) fear of greater international disorder which may occur by not helping them, and (iii) national interests arising from whatever specific economic or political considerations are relevant in the particular cases (e.g. ethnic kin, demand for labour, foreign policy) (Hans; Suhrke 1997: 104).

Steinbock sees the reason for the relatively high receptivity among Western developed countries as related to ideology: 'Under the protection of the new Convention, the Western countries often treated flight from communism, without further evidence, as sufficient to establish well-founded fear of persecution' (Steinbock 1999: 29; Sztucki 1999:73). We may conclude that many Hoa succeeded in getting resettled in the developed countries as a consequence of the ideological contest going on during the Cold War and of the economic boom in the West at the beginning of the 1980s.

\section{Conclusion}

In terms of their motivation to migrate, the Hoa from North Vietnam may be considered as 'refugees', but bearing in mind their behaviour during the migration process up to the time they reached the refugee camps of Hong Kong and Macao, we may conclude that they actually were 'migrants', because at certain points they made their own decisions on destinations and how to reach them under, evaluating possible dangers and success rates. However, the question is clearly one of perception: "The image of the "helpless passive refugee" which is characteristic for many governmental and non-governmental refugee-aid-projects was often transferred into scientific discourse' (Binder and Tosic 2002: 6; Nicholson and Twomey 1999: 3). Vrecer thinks that the term 'refugee' is not appropriate. Instead, 'forced migrant' 
would be more applicable: 'it implies that the people in question were forced to escape the country, it does not carry the negative stigma of a "passive victim" which the word "refugee" does...' (Vrecer 2002: 117). The official Vietnamese and Chinese accounts of the Hoa issue, in which both sides accused each other of having caused the mass exodus, in particular evoked the impression of a manipulated mass of people without any kind of self-determination. However, the interviews done with the Hoa living in Austria provide us with another picture. Even though they consider the páihuá policy of the Vietnamese leadership of that time as a catastrophe, in retrospect they still view this phenomenon as a chance to escape from poverty and communism, and they associate personal hope and future perspectives with the fate of leaving Vietnam. In spite of the fact that the developments in Vietnam during that time were indeed very inimical to the Hoa, the interviewees still consider themselves - however, most of them only after arrival in Austria - as having profited from the páihuá policy.

The results of the research project presented in this paper finally lead to the conclusion that neither the Chinese nor the Vietnamese leadership had the power to initiate the mass exodus of the Hoa from North Vietnam in the years 1978 and 1979. Within and despite these interstate conflicts, the Hoa were independent actors who followed their own logic and developed their own dynamic by means of a wellfunctioning information network. 


\section{REFERENCES}

Binder, Susanne, and Jelena Tosic, eds. Refugee Studies and Politics. Human Dimensions and Research Perspectives. Wiener Beiträge zur Ethnologie und Anthropologie (WBEA), vol. 15. Wien: Facultas Verlags- und Buchhandels AG, 2002

Bolt, Paul J. China and Southeast Asia's Ethnic Chinese. State and Diaspora in Contemporary Asia. Westport: Praeger, 2000

Chan, Kwok B., and David Loveridge. "Refugees in 'Transit': Vietnamese in a Refugee Camp in Hong Kong." In International Migration Review, 21/3, Fall 1987, pp. 745-759

Cohen, Robert. "The Making of Ethnicity: A Modest Defence of Primordialism." In People, Nation and State. The Meaning of Ethnicity and Nationalism, edited by Edward Mortimer and Robert Fine. London: I.B. Tauris, 1999

Dittrich, Eckard, and Astrid Lentz. "Die Fabrikation von Ethnizität." In Nationalstaat und Ethnizität, edited by Reinhart Kößler and Tilman Schiel. Frankfurt: IKO-Verlag für Interkulturelle Kommunikation, 1995, pp. 23-42

Dohmen, Holger. "Der Wortkrieg Peking-Hanoi.“ In China Aktuell, July 1978, pp. 425-433

Domanski, Maciej. "Insights from Refugee Experience: A Background Paper on Temporary Protection." In Reconceiving International Refugee Law, edited by James C. Hathaway. The Hague: Kluwer Law International, 1997, pp. 22-34

Encyclopaedia Britannica. "Fifth Column." 2011. http://www.britannica.com/EBchecked/topic/206477/fifth-column, accessed March 2011

Engelbert, Thomas. Die chinesische Minderheit im Süden Vietnams (Hoa) als Paradigma der kolonialen und nationalistischen Nationalitätenpolitik. Frankfurt am Main: Peter Lang, Europäischer Verlag der Wissenschaften, 2002

Fine, Robert. "Benign Nationalism? The Limits of the Civic Ideal." In People, Nation and State. The Meaning of Ethnicity and Nationalism, edited by Edward Mortimer and Robert Fine. London: I.B. Tauris, 1999, pp. 149-161

Gellner, Ernest. “Adam's Navel: 'Primordialists' versus 'Modernists'.” In People, Nation and State. The Meaning of Ethnicity and Nationalism, edited by Edward Mortimer and Robert Fine London: I.B. Tauris, 1999, pp. 31-35

Han, Petrus. Soziologie der Migration. Stuttgart: Lucius \& Lucius, 2000

Hans, Asha, and Astri Suhrke. "III. Responsibility Sharing." In Reconceiving International Refugee Law, edited by James C. Hathaway. The Hague: Kluwer Law International, 1997, pp. 83109

Inhetveen, Katharina. “'Because we are refugees': utilizing a legal label.” New Issues in Refugee Research. Research Paper No. 130, October 2006. Policy Development and Evaluation Service, United Nations High Commissioner for Refugees. http://www.unhcr.org/research/RESEARCH/4538eaaa2.pdf, accessed February 2007

Kempf, Gustav. Chinas Aussenpolitik. Wege einer widerwilligen Weltmacht. München: R. Oldenbourg Verlag, 2002

Kößler, Reinhart, and Tilman Schiel, eds. "Nationalstaaten und Grundlagen ethnischer Identität." In Nationalstaat und Ethnizität. Frankfurt: IKO-Verlag für Interkulturelle Kommunikation, 1995, pp. 1-21

Lamnek, Siegfried. Qualitative Sozialforschung. Beltz: PVU, 2005

Lucassen, Jan, and Leo Lucassen, eds. Migration, Migration History, History. International and Comparative Social History. Bern: Peter Lang, 1999 
Lulei, Wilfried. "Ethnic Minorities in Vietnam, Past and Present." In Ethnic Minorities and Nationalism in Southeast Asia. Festschrift, edited by Thomas Engelbert and Andreas Schneider. Frankfurt am Main: Peter Lang, Europäischer Verlag der Wissenschaften, 2000

MacCormick, Neil. "Does a Nation Need a State? Reflections on Liberal Nationalism." In People, Nation and State. The Meaning of Ethnicity and Nationalism, edited by Edward Mortimer and Robert Fine. London: I.B. Tauris, 1999

Möller, Kay. Die Außenpolitik der Volksrepublik China 1949-2004. Eine Einführung - Studienbücher Außenpolitik und Internationale Beziehungen. Wiesbaden: VS Verlag für Sozialwissenschaften, 2005

Nicholson, Frances, and Patrick Twomey, eds. "Introduction." In Refugee Rights and Realities. Evolving International Concepts and Regimes. Cambridge: Cambridge University Press, 1999, pp. $1-10$

Opitz, Peter J., ed. Das Weltflüchtlingsproblem: Ursachen und Folgen. München: Verlag C.H. Beck, 1988

Opitz, Peter J., ed. Der globale Marsch. Flucht und Migration als Weltproblem. With a preface by Mrs Sadako Ogata, United Nations High Commissioner for Refugees. München: Verlag C.H. Beck, 1997

Person 1. Interview by author. Vienna, September 2006

Person 2. Interview by author. Vienna, September 2006

Person 3. Interview by author. Vienna, September 2006

Person 4. Interview by author. Vienna, September 2006

Person 5. Interview by author. Vienna, September 2006

Person 6. Interview by author. Vienna, September 2006

Sembdner, Friedrich. Das kommunistische Regierungssystem in Vietnam. Abhandlungen des Bundesinstituts für ostwissenschaftliche und internationale Studien, vol. 33. Köln: Verlag Wissenschaft und Politik, 1978

Smith, Anthony D. "The Nation: Real or Imagined?" In People, Nation and State. The Meaning of Ethnicity and Nationalism, edited by Edward Mortimer and Robert Fine. London: I.B. Tauris, 1999

Steinbock, Daniel J. "The Refugee Definition as Law: Issues of Interpretation.” In Refugee Rights and Realities. Evolving International Concepts and Regimes, edited by Frances Nicholson and Patrick Twomey. Cambridge: Cambridge University Press, 1999, pp. 13-36

Suryadinata, Leo. China and the ASEAN States. The Ethnic Chinese Dimension. Singapore: Singapore University Press, 1985

Sztucki, Jerzy. "Who Is a Refugee? The Convention Definition: Universal or Obsolete?" In Refugee Rights and Realities. Evolving International Concepts and Regimes, edited by Frances Nicholson and Patrick Twomey. Cambridge: Cambridge University Press, 1999, pp. 55-80

UNHCR (United Nations High Commissioner for Refugees). "Flight from Indochina," 2000. http://www.unhcr.org/publ/PUBL/3ebf9bad0.pdf , accessed January 2007

UNHCR (United Nations High Commissioner for Refugees). "The United Nations High Commissioner for Refugees," 2001. http://www.un.org.vn/unag/unhcr1/unhcr.htm, accessed January 2007

Vrecer, Natalija. "Temporary Refugee Protection. A Legalised Indifference or a Solution.” In Refugee Studies and Politics. Human Dimensions and Research Perspectives, edited by Susanne Binder and Jelena Tosic. Wiener Beiträge zur Ethnologie und Anthropologie (WBEA), vol. 15. Wien: Facultas Verlags- und Buchhandels AG, 2002, pp. 111-137 
Will, Gerhard. "Vietnam.” In Das Weltflüchtlingsproblem: Ursachen und Folgen, edited by Peter J. Opitz. München: Verlag C.H. Beck, 1988, pp. 174-178

Weggel, Oskar. "Indochina. Einleitung." In Der globale Marsch. Flucht und Migration als Weltproblem, edited by Peter J. Opitz. München: Verlag C.H. Beck, 1997, pp. 164-180

Zhōngguó zhànyǒu liánméng 中国战友联盟 [The league of China's comrade in arms]. "Yuènán wàijiāobù báipíshū sānshí nián 'Yuè zhōng guānxi zhēnxiàng'” 越南外交部白皮书《三十年 越中关系真相 [White Paper of the Vietnamese foreign ministry, “The truth about Vietnamese-Chinese relations during the last thirty years"]. 1979 http://www.zywl.cn/his/200601/6.html, accessed December 2006

Zhou, Yihuan. Die Außenpolitik Chinas, transl. by Xiao Jun. Běijīng: China Intercontinental Press, 2004 


\section{GLOSSARY}

Běihăi

Cộng hòa xã hội chủ nghĩa Việt Nam

dìwǔ zòngduì

Dōngxīng
Guómíndăng
hoa kiều
huáqiáo
huáqiáo nóngchăng
jiàoxùn Yuènán
nóngchăng
páihuá

Việt Minh

zhōngguórén
北海

第五纵队

东兴

国民党

华侨

华侨农场

教训越南

农场

排华 port town in the Chinese province of Guăngxī 广西

(Viet.) Socialist Republic of Vietnam, SRV

fifth column; the term describes a group of subversive elements within a country who are loyal to another power and work against local authorities town at the Chinese-Vietnamese border in the province of Guăngxī 广西 Chinese National People's Party, founded on 12 August 1912 by Sun Yat-sen (Sūn Yìxiān 孙逸仙)

(Viet.) overseas Chinese overseas Chinese state-owned farms for overseas Chinese returning to the PRC to teach Vietnam a lesson farm abbreviated form of páichì huárén 排 斥华人, can be translated as “displacement of ethnic Chinese". Páihuá is defined as a discriminative policy of the Vietnamese leadership, aiming at disadvantaging ethnic Chinese especially in terms of access to higher education and within the labour market (see interviews 2007)

(Viet.) abbreviation for Việt Nam Độc Lập Đồng Minh Hội-League for the Independence of Vietnam Chinese 